\title{
The Translation Strategy of Slang Expression in Comic Entitled The Punisher
}

\author{
Dwi Santika
}

\begin{abstract}
Abstraks
Penelitian ini membahas tentang strategi penerjemahan ungkapan bahasa slang dalam sebuah komik yang berjudul The Punisher. Komik ini diterjemahkan dari bahasa Inggris ke dalam bahasa Indonesia oleh Hindi R. Ibrahim. Adapun tujuan dari penelitian ini antara lain: pertama, untuk mengidentifikasi jenis-jenis ungkapan bahasa slang yang ada dalam komik The Punisher. Kedua untuk menjelaskan strategi penerjemahan ungkapan bahasa slang dalam komik The Punisher. Penelitian ini menggunakan metode deskriptif kualitatif. Sebagai alat pengumpul data, peneliti melakukan beberapa hal, antara lain: membaca komik The Punisher dalam bahasa Inggris dan Indonesia; menandai ungkapan bahasa slang dan menyeleksinya untuk diklasifikasi berdasarkan jenis dan strategi penerjemahannya menurut teori yang ada dalam beberapa sumber. Hasil temuan penelitian ini menyatakan bahwa terdapat empat tipe ungkapan bahasa slang dalam hasil terjemahan komik The Punisher, identifikasi-kelompok, kreatifitas, privasi, dan sekresi, (informalitas dan intimasi, vulgaritas dan ofensif). Adapun strategi penerjemahannya antara lain, penghalusan, secara literal, dan kompensasi stilistika.
\end{abstract}

Katakunci: Strategi penerjemahan, ungkapan slang, komik, The Punisher, kompensasi stilistika

\begin{abstract}
In this research, the researcher concerns with translation study, that is, the translation strategy of slang expression in comic entitled The Punisher translated by Hindi $R$. Ibrahim. The objectives of the research are: (1) to identified the type of slang expression based on its function used in the target language, (2) to describe slang translation strategy applied in the translation. The researcher uses qualitative descriptive method in order to reach objectives of the research. The researcher employs herself to collect data; by reading the comic and its translation, marking the slang expressions, classifying, selecting and analyzing them based on the type of slang theory and slang translation strategy theory which are taken from some relevant references. Findings of this research show that: first, the four types of slang expression are used in source language $n c \backslash u d e g r o u p-i d e n t i f i c a t i o n$ and creativity, privacy and secrecy, informality and intimacy, andvulgarity and offensiveness; second, all strategies applied in the translation they are literal softening, literal translation and stylistic compensation.
\end{abstract}

Keywords: Translation strategy, slang word expression, comic, The Punisher, stylistic compensation. 


\section{INTRODUCTION}

As human being, we need language to interact, associate and establish social contacts in a community or society. Language is one of the ways for human being to communicate to each other. Language itself is divided into two, they are formal language that we can see in newspaper and non-formal language such as slang. Hartmann and Stork in A. Chaedar states that "Slang is a variety of speech characterized by newly coined and rapidly changing vocabulary, used by young or by social and professional groups for 'in-group' communication and thus tending to prevent understanding by the rest of the speech community." The statement above shows that slang is a language variation which commonly used by teenagers and a certain group.

The use of slang in society similar with fashion. Widarso states in his book, "Slang seperti fashion: muncul, semua orang menggunakannya dan mudah ditemukan di mana saja" (slang like a fashion: appears, everybody use it and it is easy to find everywhere). The statement above describes that slang can be used by everyone without considering their gender or class. People have their own reason when using slang expression. To induce either friendliness or intimacy of a deep or a durable kind, to show that someone belongs to a certain group, to be secret and many more.

The using of slang is not only found in country with English as its first language. For example Indonesia which using English as foreign language. Indonesia has its own slang expression; Prokem or Bahasa gaul is a technical term that Indonesian people use to call slang.

\footnotetext{
${ }^{1}$ A.Chaedar Alwasilah, Sosiologi Bahasa, (Bandung:
} Angkasa Bandung, 1985), p.57.
The words such as kudet (kurang update), jayus (tidak lucu), woles (derived from slow means santai), unyu (lucu, menggemaskan) are only a few of so many slang expressions in Indonesia.

One slang may have many meanings depend on when and where the speaker use it. It means, the translator must familiar with the type of slang expression itself. A function of the slang expression that is used in certain situation is where a translator have to give more attention. For example, "I'd rather not be left stuck to your crappy car..." The statement is said by a hostage. The situation of the text is Hector (drugs mafia leader) forcedly to go into his enemy's car. The slang expression above has vulgarity and offensiveness function since it is used to bad mouthing. Different with this example "this place such a crappy!" the slang expression has informality and intimacy function because it is used to describe frightening place and the situation of the sentence above is between friends.

After knowing the type of the slang expression, the translator may face another problem. The diversity of language and its variation, especially slang caused communication between two different languages turn into difficulty.

As we know that translation is the process of transferring a message from source language (SL) into target language (TL). A translator should not translate text carelessly, epecially in translating slang expression. The difficulty of slang translation is primarily related to the difficulty of slang interpretation. If and when a translator succeeds in understanding slang, then they succeed in translating slang.

In translating slang, translators may have many jobs. They have to show their resourcefulness, creativity and also find 
proper strategy to be used, so that it will not lead misinterpretation among receptors. Even, the job of translators may become harder when they are translating a comic. Because strategy is base step for a translator to determine how are they bring readers to destination. Destination here means a success translation. The wrong strategy that the translator use, it will bring reader to misinterpretation.

Slang is bound to a culture. There are some limitation that slang can be translated. In order to transmit cultural terms (for example slang) properly and accurately, first, a translator should first know the source and target language thoroughly. Second, the translator should be accustomed to the cultural customs, religious, beliefs and historical backgrounds of the two texts, and finally she/he needs to have proper understanding of the subject matter and the dominant concepts in the text.

In this case, the researcher chooses comic as unit analysis. Comic looks attractive because consists of pictures, icons, texts, and plot; and it makes comic is a kind of literary forms. As Will Eisner states, "comic means of creative expression, a distinct discipline, an art and literary form that deals with the arrangement of pictures or images and words to narrate a story or dramatize an idea." 2

One of the problems in translating comic, especially western comic is translating slang expression that is bound by culture, in which a translator must find an exact meaning for an event or something that is strange in receptor language culture. To solve this problem, it is necessary for a translator to find a

${ }^{2}$ Will Eisner, Comics and Sequential Art, (United states: Poorhouse Press, 2006) p.5. certain way or strategy to obtain similar meaning, effect or intention of source text author. For example, in a comic, there is a slang phrase binge-watch which translated into bahasa Indonesia nonton sambil minum. Absolutely, the transaltion is acceptable for the readers, because it is comprehensible. In the translation, the slang phrase is translated literally but the translator is soften the word to make the translation sounds natural with the reader. This way is one of the translation strategies, which is mentioned as literal softening. Literal softening is used to produce a natural translation.

From the explanation above, the researcher tries to analyze the slang expression from American comic series by Marvel Publishing, The Punisher. Slang is interesting and important to be familiar with. The researcher chooses slang expression because slang is not a word or phrase which only have direct meaning and it sometimes make reader confused or even misunderstand. The researhcer also chooses The Punisher comic as unit analysis because the comic is originally using English and have many slang expressions. In this case, the researcher will take two parts of the comic. First part title is Memento Mori and the second part title is Coyote.

This research has some similarities with some other research which have similar topic. The first previous research is a thesis entitled "An Analysis of Slang Expression Translation in Mean Girls Movie" written by Nur Ardyasari Ratna Ningrum in 2009 from Sebelas Maret University. ${ }^{3}$ In this thesis she focuses on describing the translation strategy and the

${ }^{3}$ Nur Ardyasari Ratna Ningrum, An Analysis of Slang Expression Translation in Mean Girls Movie, (Surakarta: Sebelas Maret University, 2009), p.11. 
impacts of the strategy to the accuracy and acceptability of slang expression translation in Mean Girls movie. She employed descriptive qualitative method. She uses the 8 translation strategies from Mona Baker they are translation by more general word; translation by a more neutral/less expressive word; translation by cultural substitution; translation by using a loan word or loan word explanation; translation by paraphrase using a related word; translation by paraphrase using unrelated word; translation by omission; and translation by illustration. The result shows that the 8 translation strategies are applied in the Mean Girls translation movie. She concludes that the translation by more general word is the most common strategy. After spreading some questionnaires, she finds out that the impacts of the strategy makes the level of acceptability and accuracy is not really high. The use of common word or phrase usually caused by the lack of equivalence of slang expressions in target language.

The second prior research is still a thesis which taken from Della Mayvalencia "An Analysis of Meaning Equivalence of English Slang Language Translation in Whild Child Movie Text". In this thesis, she focuses on analyze the English slang language in the text and how it is translated into Indonesian language in Wild Child movie and the aim of the research is to know how the meaning equivalence between translated text and the original text. She uses descriptive qualitative meethod. She states that jargon, argot, and colloquial are varieties of slang. She uses the equivalence strategy from Eugene A. Nida and Mona Baker namely formal equivalence; dynamic equivalence; cultural equivalence; grammatical equivalence; and pragmatic equivalence. The result show that the equivalence in the translation consists of all type of equivalence.

The last previous research is a journal, entitled "Slang Translation: A Comparative Study of J.D Salinger's The Catcher in The Rye" written Habibollah Mashhady and Maryam Pourgalavy in 2013..$^{5}$ In this research they focus on analyze the slang translation in dialogues from English into Persian using the model proposed by Venuti. Whether the translation is domesticated or foreignized. The result indicates that the most frequently employed translation strategy for transferring slang in "the Catcher in The Rye" is domestication. However, using foreignizing strategy can reproduce the original picture and truthfully essence of the ST, especially to the parts where the source culture is different from the target culture. It is good for combining two cultures and is beneficial for keeping the characteristics of the SL texts. Nevertheless, they states that it may cause an information overload and cultural shock, and thus may be difficult for the TT readers to accept and understand the translation. Since in the translation of slangs as culture-specific items, it is better to find target equivalents for the unfamiliar and unkown terms instead of remaining them untranslated or using neutral terms, and if the translators cannot

\footnotetext{
${ }^{4}$ Della Mayvalencia, An Analysis of Meaning ${ }^{5}$ Habibollah Mashhady and Maryam Pourgalavy, Slang Equivalence of English Slang Language Translation in Translation: A Comparative Study of J.D Salinger's The Whild Child Movie Text, (Jakarta: UIN Syarif Catcher in The Rye, (Finland: Academy Publisher, Hidayatullah, 2011), p.1. 2013), pp. 10031010.
} 
find the appropriate target equivalents, they can use foreignization strategy and retain cultural terms so that the TL readers understand about the source language culture.

From the previous research above, there are some similarities and differences with this current research. First similarity from all the research including this current reseach is focus on translating slang. The differences can be seen in the aim of the research. First research purpose is to describe the translation strategy and the impact after the strategy applied. The second research purpose is to know the equivalence between SL and TL and the last research is focus on the product of the translation whether it is foregnized or dometicated. However, this current research is focus on analyzing the type of slang based on its function in SL and TL. Then find out whether the uses of translation strategy is suitable or not. The strategy used here is also examins Karolina Butkuviene and Lolita Petrulione which states that there are three main translation strategies commonly used in translating slang they are literal softening, literal translation and stylistic compensation.

\section{A. DISCUSSION}

There are some kinds of language varieties that are used in informal context of communication, one of them is slang. Slang is the most common style in informal setting, especially in young generation or teenagers. It can serve a bridge, either helping both old and new words that have been used as "insiders" terms by a specific group of people to enter the language of the general public or, on the other hand, preventing them from Ibid. doing so. Despite the difficulty of defining Ibid. slang, some linguists try to give their own definition about slang. Dumas and Lighter, cited in Eble, describes four criteria for deciding whether a linguistic item constitutes slang, they are:

1. Its presence will markedly lower, at leasr for the moment, the dignity of formal or serious speech or writing;

2. Its use implies the user's special familiarity either with the referent of people who have such familiarity and use the term;

3. It is a tabooed term in ordinary discourse with person of higher social status or greater responsibility;

4. It is used in place of the wellknown conventional synonym, especially in order (a) to protect the user from the discomfort caused by the conventional item or (b) to protect the user from the discomfort or annoyance of further elaboration.

Here is a selection of Dumas and Lighter's examples:

Though their dissent was not always noisy or dramatic, many Americans

felt the President was a jerk for continuing the war.

Speaker A: "What should we do with the prisoners, Lieutenant?"

Speaker B: "Waste 'em.",

Speaker A: "I'd like this job, sir, because the one I have now is shit."7

According to the criteria, jerk, wastem and shit all qualify as slang. Jerk fulfills criteria 1,2 , and $4 \mathrm{~b}$; waste, criteria 1, 2, and 4a; and shit, criteria 1, 2, 3, and possibly $4 \mathrm{~b}$. 
Slang is a phenomenon which shows diversities among different languages and which is supposed to be difficult to reproduce in translation. The translation of linguistic varieties that belong to socially restricted speech community, such as slang which is rarely have equivalents. Since slang is a cultural phenomenon, the main problem of slang translation arise because of the differences in language systems and cultures. Thus, when the differences between languages and cultures are extremely great, the translator should be ready to perform various shifts during the process of translation as well as to choose the right translation strategy. ${ }^{8}$ Translators should be aware that their translation corresponds to certain culture, readership, and conveys the proper meaning.

1. Types of Slang

There are 4 types of slang expression based on its function, these are the

following types:

\section{Creativity}

a) Group-identification and

The function of identification with a group and the effect of creativity are particularly evident in college and teenage slang. Youth generally use creative innovative slang to show their belonging to a group and establish solidarity with the other group members, keeping the older generation at a distance. Look at the example below:

Sonny : "Come on, Doody."

Doody: "Watch out!"

Sonny : "Putzie, move it out!

JOLANTA LEGAUDAITE, UNDERSTANDING SLANG IN TRANSLATION, (Vytauto Didziojo Universitetas: FILOLOGIJA, 2010) Vol. 15, pp. 92-93. Accessed (http://vddb.library.lt/fedora/get/LT-eLABa0001 :J.04 2010 ISSN 1392-561X.N 15.PG 9198/DS.002.1.01.ARTIC)
It's like a meat-ball in here!"

Putzie : "Let's go to find the chicks",".

The speakers in conversation above are high school students of the Rydell High. They share sex, age, education, and belong to the same gang, the T-birds. In the extract above, three ,T-birds' (Sonny, Doody and Putzie) come out of the hatchback of a car parked in an open-air cinema.

The term chick is commonly used for "a young chicken; sometimes the young of any bird", or occasionally as a term of endearment applied to human offspring. However, chicks is peculiarly used with the different slang sense of "girls; young women". Here it serves to identify the speakers as belonging to a specific group (male teenagers) and show their need to be fresh and to play, creatively, with words and their meanings.

b) Privacy and Secrecy

The function of privacy and secrecy are related to marginal or isolated sub groups in society, such as criminals and drug addicts. ${ }^{9}$ Criminals, for

instance, generally use slang to hide information from people in authority, while drug addicts adopt the slang vocabulary to reinforce their group cohesion, in the other hands to keep insiders together and outsiders out. The example below is a boys' conversation about some illegal drug traffics. Sick boy tries to persuade one of his mates, Mark Renton, to buy some drug:

Sick Boy: "There is a mate of Swanney's. 
Mikey Forrester - you know the guy. He's come into some gear. A lot of gears ",

Renton: "How much?"

Sick Boy: "About four kilos. So he tells me. Got drunk in a pub down by the docks last week, where he met two Russian sailors. They're fucking carrying the stuff. For sale there and then, like." 10

This extract illustrates the use of two terms (gears, stuff) that normally refer to "goods, matter or substance of any kind". However, they convey a new specific sense among drug dealers (i.e. "(illicit) drugs, narcotics"), becoming marked in terms of transparency and biuniqueness, and making the conversation private and clandestine.

c) Informality and Intimacy

The function of informality and the effect of intimacy are self-evident

in general slang, which is language that speakers deliberately use to break with the standard language and to change the level of discourse in the direction of familiarity. ${ }^{11}$ It signals the speakers' intention to refuse conventions and their need to be colloquial, to ease social exchanges and induce friendliness. The speakers below (from Notting Hill) are the

bookshop owner William Thacker, a typical middle-class Londoner, and his slovenly flatmate Spike. Here they talk about an underwater mask:

Jimmy : :Hey! You dog, you."

Michael : "I'm a bit of a $d o g$. Thanks so much Jimmy." Jimmy : "Hey, all the best, huh?"12

Jimmy addresses Michael by using the intimate slang appellative dog. The term $d o g$ is often reported in slang dictionaries with a wide variety ofmeanings and used with both positive and negative connotations (e.g. "afriend", "a foot", "a sexually unattractive person", etc.) Despite this, it is also the standard name of "a carnivorous mammal", and an abusive term for "a cur, a wretch". The result is vagueness and low transparency.

d) Vulgarity and Offensiveness

The function of vulgarity regularly combines with an effect of offensiveness in general slang, particularly in slang which is used by speaker to criticize other people's appearance or behavior. ${ }^{13}$ It signals the speakers' intention to be rude and impolite, making use of improper language, and of derogatory, even taboo words that often allude to the semantic area of 'sex'. The example below is taken from NottingHill. The speakers are two friends of William who disapprove his behaviour with the famous actress Anna Scott:

Honey : "William's just turned down Anna Scott." prick."

Spike : (to William) "you daft

The term prick, used by Spike, is a derogatory slang expression referring to "the penis", but also "a vulgar term of abuse for a man". It shows another effect of slang (offensiveness) produced by the speaker's choice of a rude lexically marked word to address someone he criticizes or condemns.

Ibid.

Elisa Matiello, (2007) Op. Cit., p. 122.

Ibid. 


\section{Typical of Slang}

Slang is not a usual word which does not have something special in it. It has its own typical. Some of them are:

a) Slang is typical of informal situation

The formality of language is tied to the situation: in formal situation people expect formal language and in non-formal situation they expect informal language. Slang tends to be rude if we use it in formal situation. Therefore, slang is frequently be the last choice for people who have business purpose. Slang is more familiar among youth with the same age (among friends) than among employee.

b) Slang is typical of spoken language

Since the situation in which we write are more formal that the situations in which we talk, as stated above that slang is typical of formal situation, automatically slang belong to typical of spoken language. We rarely found slang words in written language. But the statement before does not mean we could not see any of them in written work. Comic is an example. We will find various types of slang, especially in youth comic. It will not be hard to find slang words there.

c) Slang is found in words, not in grammar

Every language contains vocabulary and grammar. Since there is not grammar of slang, slang cannot be considered as language. That is way, when people talk about slang; it is referred to words not grammar or pronunciation.

d) Slang is not swearing the expression refers to something that taboo in cultural and usually express strong emotions and attitudes. That is definitely different with slang. Even though slang terms may contain some taboo words, but it is used for fun or joking among friends and the important this is that slang words used without emotion.

e) Slang is not register

Register is specialized vocabulary owned by specific occupation and activity. Registers are different with slang, but may contain slang, as long as the specialized vocabulary is informal. In the medicine terms, for example, when a patient leaves a tissue sample of examination, the doctor may say that they are sending some meat to the laboratory.

These words are learned and used in practice and none of those words are written in the books of medicine. Most of register associated with unofficial, or illegal activities may consist a lot of slang. ${ }^{14}$ Like the narcotic business, industries that involve very many people and lies on the fringes often find its way out of this register and into general slang vocabulary. Words such as high, stoned, freaked out, turned on, which related to the effects of drug abuse, shifted their way into slang words. In the other hand, slang is like term which owned by one certain field.

f) Slang is not cant, argot or jargon

For the first time, the term slang was used in British criminal to refer to their own special language. Cant, a private language of the underworld (criminal) which still used as a term for language of criminals. Thus, slang has moved a long way from its origin. Argot is a name for the language criminals which origin is

Swearing is type of language use in whith Ibid. 
French and has been used for several centuries with this meaning. Jargon refers to special or technical words used by particular group of people.

From the passage above, the researcher conclude that Cant and argot are special words among criminals and only them who know the meaning. While Jargon is the words used by certain people in a certain situation. Different with slang which is the words used intensely among youth no matter where and when.

\section{g) Slang is creative}

Creativity took an important part in the invention of many slang words. The point of slang words is often to be starling, amusing or shocking. Slang expressions, for example, the apple of one's eye (one favorite), square heads (stupid person), for the first time they are used, they are truly creativity. Those words attract other people's attention. People who use slang words in every their chat, then they are included to creative people.

h) Slang is short-lived

As stated before, that is unusual for slang words to stay on the language for thousand years. Most of slang words are accepted into neutral style or else die out rather quickly. Many slang words, such as phone, bike, bus, pub, etc., have become standard or neutral language. There are also many slang words which have been lost.

Same like language, slang somewhat always changing through time. Every slang word will be change or develop. Later, the slang word will be the ordinary colloquial or it will develop to be a word with numerous meanings.

3. Slang Translation Strategies

Recreating the same effects in a different language community by means of an equivalent slang formation is nearly impossible. Yet, according to Karolina ${ }^{1}$
Butkuviene and Lolita Petrulione there are three general slang translation strategies; they are softening and literal translation which derived from Eugene Nida and stylistic compensation by Keith Harvey. These are the following definitions:

a) Literal Softening is focused on the perception of the target text reader; the language of the target text is formulated in such a way that it sounds natural and comprehensible for the reader. The purpose of softening effect is to soften the rudeness and vulgarity of slang when it contains negative connotations or its usage is inappropriate in the translation, for this reason the other word with the proper meaning is chosen. This translation strategy is particularly useful in the translation of dirty slang words, denoting sex and swearing, since they are especially censored in translation of the target language (TL). For example: "Hi, gay!" translated to "Hai, penyuka sesama! ”. The word "gay" was translated to "penyuka sesama" which is softener to be heard. While in literal translation, we can use the word "homo".

b) Literal translation or known as word-for-word translation is used when words of the source language are translated directly into the target language. ${ }^{15}$ According to Vinay and Darbelnet, literal translation is the direct transfer of ST into a grammatically and idiomatically appropriate TT in which the translator's task is limited to observing the

Ibid., p.86. 
adherence to the linguistic servitudes of the TT". Fawcett referring to the literal translation strategy indicates that it is "the rare but always welcome case when a text can go from one language into another with no changes other than those required by the target-language grammar). ${ }^{16}$ It is appropriate to translate words literally whenever it is possible to find the equivalents in TL.

However, the literal translation is commonly used in translation if the ST and TT languages belong to the same family or they share the same or very similar cultures. Furthermore, this strategy of translation may be appropriate in the translation among the European language some of which share the concepts of the culture and the civilization, have certain kinds of similarities in the way of thinking or structuring the language patterns. The use of this strategy of translation is becoming more widely used in the case of slang translation. Slang can be translated into TT, if only its equivalent is available. Therefore, the style of the TT has to be kept close to the ST as much as it is possible and if it is not, the other translation strategy should be chosen. For example: "This place is like hell!" translated to "Tempat ini bagai neraka!". The sentence above was directly translated as it is in source language. There was no change at the form and or the meaning.

c) Stylistic compensation. According to Harvey, stylistic compensation involves making up for the loss of a source text effect in the target text using the means specific to the target language or text. By the use of
Ibid. stylistic compensation strategy, it is possible to use slang in the TT and achieve similar effect to the ST, but if it is not possible to do, the translator can choose other option.

Usually this strategy is used to solve the problem of the translation loss and try to achieve the effect of the target text that is similar to source text. Stylistic compensation helps to solve the language and culture specific problems that occur in the translation of slang, but the translator should decide whether it is worth to translate a certain linguistic item and they should try keep to the proper style of the text as much as possible. For example: "It's raining cats and dogs!" translated to "Hujan deras sekali!". The phrase above do not have the exact meaning in target language (Bahasa Indonesia), that is why the translator maintain the effect of the source language and keep the meaning the same.

In this data description, the researcher wants to discuss the slang expressions which taken from The Punisher comic series by Nathan Edmonson, which was published on February $05^{\text {th }}$, 2014 for part 1 and February $19^{\text {th }} 2014$ for part 2 and the translations are from Hindi R. Ibrahim.

From the corpus data above, the researcher will analyze and classify the selected slang expressions by categorizing its type based on its function and describe the meaning, then analyze the translation using the slang translation strategies.

Besides, the researcher will finds out the meaning of slang from some slang 
dictionaries, such as The Concise New Partridge Dictionary Slang and Unconventional English, Dictionary of American Slang and Random House Historical Dictionary of American English. To get further description of analysis, the researcher tries to illustrate as follows:

1. Binge-Watch

SL: .. I'm going to binge-watch some „,50s TV shows and actually, maybe, sleep. (p. 1)

TL: ... Aku mau nonton acara tahun 50an di TV sambil minum.

Mungkin juga aku tidur.

Illustration: a group of soldiers are talking in the helicopter. One soldier (named Moffly) tells the others about what he will going to do after the mission.

The slang expression "bingewatch" is translated to "nonton...sambil minum" " in TL. The word "binge" means a dringking or drugging spree. ${ }^{17}$ The speaker in the comic uses a slang expression "binge-watch" which means going to watch TV shows and drinking alcohol at the same time.

This slang expression in ST is group-identification and creativity because the speaker uses the slang expression to show the speaker's belonging to a specific group (soldier and men group) and show the speaker's need to be fresh by playing with words creatively and their meaning; while in TT, this slang expression has changed to be an ordinary daily word (colloquial). Yet, if the colloquial above is a slang, it can be concluded

Eric Partridge, The Concise New Partridge Dictionary of Slang and Unconventional English, (New York: Routledge, 2008), p.32. that its type is informality and intimacy.

After knowing the meaning in the translation and understanding the type, the slang expression here can be categorized as literal softening strategy. It is more appropriate that the other strategies because the word "nonton...sambil minum" sounds natural and comprehensible for the reader without mention alcohol which sounds inappropriate for readers in TL. Later, even though the researcher did not mention wants to analyze the equivalence, but a fact that equivalence can not be avoided from translation, the researcher concludes that the translation has formal equivalence because although it is different in form, but the meaning is still accurate and correct.

2. Goth Bling SL: Goth bling? (p.8)

TL: Cincin gothic?

Illustration: "the Punisher" (Frank) answered his friend's question about what he has been holding.

The word "Goth" is an abbreviation of a noun "Gothic" which means a member of youth fashion cult, characterized by a dark, sepulchral appearance and stark white and black make up; ${ }^{18}$ while the word "bling" is a noun which means a vulgar or ludicrously ostentation display of wealth. The data above shows that the slang expression has informality and intimacy function. It identified that the speaker in the comic uses the slang expression to ease social exchange and induce friendliness. The slang expression "Goth Bling" is translated into "Cincin gothic". It is stylistic compensation because it has similar responds although the translation is not

Eric Partridge, Op. Cit., p.301. 
into direct lexical meaning. Yet, the translation here has achieved the same effect.

Despite the fact that the word Gothic is not Bahasa Indonesia, the translation may have the same effect on the reader as the original, since the word Gothic is well-known or familiar in TT readers. The equivalence of the translation with ST is dynamic. Although there is no change in structure between ST and TT, it still comprehensible for readers in SL, and in accordance to the meaning, it can be categorized into dynamic equivalence.

1. Hombre

SL: ...Bra chafe is no joke, Hombre. (p.8)

TL: ...Aku tidak bercanda, anak rumahan.

Illustration: a friend (female cop) called "the Punisher" (Frank) to tease him. In this case, "Hombre" is translated to "anak rumahan". The slang expression "Hombre" itself derived from HAHM bray means a Hispanic person, a man, a fellow. According to the comic, the speaker uses the slang expression "Hombre" to call a friend whom she talks to. This slang expression has informality and intimacy function. It because she wants to make her conversation feels warmer and closer. However, if the phrase anak rumahan above is a slang, the type is the same with the SL, informality and intimacy.

The data above classified as stylistic compensation strategy. The fact that direct lexical meaning is not available in TL, it caused there is a loss in translation. That is why composing other meaning with different form is acceptable in order to make the same effect among readers. Stylistic compensation is correlated with dynamic equivalence. It means, this slang expression translation is dynamic equivalence because it focuses on TL reader's perception.

2. Hell of a Nest

SL: Hell of a nest, Hector. (p.12)

TL: Sarang neraka, Hector.

Illustration: "the Pusniher" talked to himself about a place that full with drugs mafia.

The slang expression in data above means an extremely bad place. ${ }^{49}$ Informality and intimacy is a type of this slang expression because according to the comic, the speaker uses the expression to describe a place that is full with gangster. As usual, in translation, the researcher finds the slang expression has changed into colloquial.

To sum up, the researcher finds out that the translation is applying literal softening strategy. The slang expression here is used to insult something; while in translation, the expression looks more soft and acceptable because it does not use any rude word. In addition, the slang expression translation is dynamic equivalence, since it focuses on reader response.

3. Jerk

SL: Hey, Jerk! Get back in your car! (p.13)

TL: Hey, bego. Balik ke mobil!

Illustration: a driver behind the Punisher's (Frank's) car mad at him because he stopped his car suddenly and make a mess with his weapon.

The slang expression "jerk" is translated to "bego" when the true meaning is an idiot or a 
fool. ${ }^{19}$ While, Meriam Webster describes the slang expression "jerk" literally means a person whose behavior is offensive to others. $^{20}$ The speaker in the comic uses the slang expression to throw his anger. It means the type of this slang expression is vulgarity and offensiveness. Meanwhile in translation, the researcher is not found any type of slang because the form is changed into colloquial.

In accordance of the explanation above, the researcher concludes that the translation is applying literal translation strategy. It can be seen from the translation, there is no change in form and meaning. Yet, the translation is still acceptable for readers in TL. Literal translation strategy is always connected with formal equivalence which focuses on the accuracy of meaning. So, the researcher sum up that the translation is formal equivalence.

4. Crappy

SL: ... I'd rather not be left stuck to your crappy car- (p.16)

TL: ... Aku tidak ingin terjebak di sini dalam mobil bututmuIllustration: the Pusnisher (Frank) forced Hector (Drugs mafia leader) to go inside Frank's car. Then, Hector insulted Frank's old car.

The slang expression in

${ }^{19}$ Ibid., p.365.

${ }^{20} \mathrm{http}: / / \mathrm{www} \cdot \mathrm{meriam}-$

webster.com/thesaurus/jerk\%5Bnoun\%5d. Accessed August $22^{\text {nd }}$,

2014. data above means inferior quality or poor condition. "Crappy" has a function as vulgarity and offensiveness because the speaker uses this slang expression to insult something. According to the comic, the speaker uses the slang expression to describe an old car of Frank's (The Punisher). In TL, a colloquial is used, that is "butut".

After knowing the meaning and understanding the type, the translation is applying literal softening strategy. The application of this strategy in this slang expression translation is more appropriate because TT has given the exact meaning and it also undertsandable because it as the same responds among readers both in SL and TL. As the conclusion, the researcher decided that the translation is dynamic equivalence because it concerns on reader's responds.

5. Pigs

SL: Hey, Man! Don't leave me here for the pigs! (p.17)

TL: Hey, bung! Jangan meninggalkanku di sini bersama babibabi itu! Illustration: Hector (Drugs mafia leader) shouted to the Punisher (Frank) to not leave him alone for Dos Sols' gang.

The slang expression "pigs" means inferior or bad example of anything; an unpleasant person. The type of the slang expression is vulgarity and offensiveness because the speaker uses this slang expression to describe drugs mafia and its member. While in TT, the slang expression is changed into colloquial. According to the comic, the speaker uses the slang expression to 
refer the gangster.

From the described meaning in above, the translation uses literal translation strategy to translate the slang expression. The application of this strategy in this slang expression translation is acceptable and it means the translation is formal equivalence.

6. Loaded Clip

SL: Everyone has a loaded clip when Punisher is around. Good and bad. (p18)

TL: Semua jadi sibuk saat Punisher muncul. Orang jahat, orang baik. Illustration: Hector (Drugs mafia leader) shouted to the Punisher (Frank) to not leave him alone for Dos Sols' gang.

The slang expression in data above is informality and intimacy because the conversation occured between friends. According to the comic, the speaker uses the slang expression to describe what people's activities are when the punisher is around. The slang expression "loaded clip" itself means many paces or rates. ${ }^{54}$ The slang expression in translation is "sibuk". It means the slang expression in the TT has changed into an ordinary daily used word (colloquial).

From the described meaning in the SL above, the translation is applying literal softening strategy. The application of this strategy in this slang expression translation is acceptable because the TT has given the exact meaning and understandable because it has the same responds both in SL and TL. Yet, there is a change in form of word that caused the translation is dynamic equivalence because the translation is more focus on reader's response.

SL: It won't be easy, he's a pro. (p.19)
TL: Itu tidak akan mudah. Dia ituprofesional.

Illustration: one of Howling Commando's (elite troop led by Director

S.H.I.E.L.D Nick Fury) member talk to the others.

The slang expression "pro" is translated to "profesionar. The slang expression "pro" itself is an abbreviation of profesional. ${ }^{55}$ Informality and intimacy is the type of the slang expression because the speaker uses it to break the standard language. According to the comic, the speaker uses the slang expression to describe a person's greatness in killing people.

From the described meaning above, the translation here can be categorized as literal translation strategy. It can be proved because the translation is directly transferred from SL. At last, the researcher concludes that the translation here is formal equivalence.

$7 . \quad$ Damn

SL: Oh Damn, just a Coyote! (p.6)

TL: Oh! Sial cuma anjing liar!

Illustration: Dos Sols' member talk to the other member.

Acording to the data above, "Damn" is rendered into "sial" The slang expression "Damn" means something of little or no worth. ${ }^{21}$ The slang expression type above is vulgarity and offensiveness. The speaker uses the slang expression to express his shock over a dog. Meanwhile in TL, the slang expression has changed into daily used word (colloquial).

After knowing the meaning and understanding the type above, the 
translation can be classified as literal translation strategy. Considering the fact there is no change in meaning and there is no extra meaning added. The slang expression translation also can be categorized as formal equivalence because it is strongly influenced in determining the accuracy and correctness.

8. Doggy Bag

SL: Two sausage sandwiches, Lou. In a doggy bag. (p.8)

TL: Dua sandwich sosis, Lou. Bungkus. Illustration: the Punisher (Frank) ordered some food to Lou (Cafe Waiter and Frank's friend) .

The slang expression type in data above is informality and intimacy. According to the comic, the speaker uses the slang word to express his desire to bring the food home. The slang expression "doggy bag" is translated to a daily used word or colloquial "bungkus". It is similar with the true meaning, "doggy bag" means a bag in which uneaten food from restaurant is packed and taken home.

In accordance to the type and the meaning above, the translation here can be classified as stylistic compensation strategy. The application of this strategy in this slang expression translation is more appropriate than other strategies because there is no direct lexical meaning which caused mae up the loss of translation is needed; and the word "bungkus" is match to cover up the loss as long as the intention of the author in SL is welltransferred and reader in TL is understand. It means the translation is dynamic equivalence.

9. Ammo

SL: They're not running out of ammo! (p.11)

TL: Mereka punya banyak amunisi!

Illustration: a male cop talked to the female cop.

The slang expression type, "ammo" is group-identification and creativity. It is because the slang expression is used in cop's talk; while it can be seen that the slang expression is changed into daily used word or colloquial. According to the comic, the speaker uses the slang expression to refer a bullet supply of villains. The "ammo" itself is an abbreviation of ammunition. From the described meaning above, the translation here can be categorized as literal translation strategy. It is because there is no change in form and meaning. Then, formal equivalence can be seen from the translation directly since it always correlated with literal translation.

10. What in the Hell SL: What in the hell. (p.16)

\section{TL: Apa-apaan ini?}

Illustration: the Punisher (Frank) fell down from his motorbike because he was attacked.

The type of slang expression "what in the hell" is informality and intimacy. According to the comic, the speaker uses the slang expression to express his shock. In translation, "what in the hell" is translatedd to "apa-apaan ini?"

The slang expression "what in the hell" itself used in annoyance, resignation or surprise. ${ }^{22}$ From the described meaning above, the translation can be classified as stylistic compensation strategy. The application of this strategy in this slang expression translation is acceptable because the TT has given the same meaning and understandable because it has

\footnotetext{
${ }^{22} I$ Ibid., p.695.
} 
the same responds both in SL and TL. It means the translation is dynamic equivalence.

11.PCH

SL: --you need to hear this. Something's going down on the PCH. (p.19)

TL: --kau harus mendengarnya. Sesuatu yang penting telah terjadi di jalan Santa Monica.

Illustration: a member of a gang talked to his leader.

The slang expression in data above is group-identification and creativity because it used by people who staying in America only which is only a certain group familiar with the slang expression. According to the comic, the speaker uses the slang expression to refer a highway located in Santa Monica.

The slang expression "PCH" is translated to "Santa Monica" the "PCH" itself is an acronym of Pacific Coast Highway which located in Santa Monica. ${ }^{23}$ From the described meaning above, the translation here can be categorized as stylistic compensation strategy. It is more appropriate strategy because there is a loss in the translation. The meaning in TL is not the exact meaning. But, to cover up the loss, a familiar word used in translation in order to make comprehensive translation for reader. In conclusion, the translation here is dynamic equivalence which focuses on reader understanding.

To sum up, literal translation and stylistic compensation strategies appears most frequent. It can be proved from 5 out of 14 data analysis, for example "jerk ^ bego", "pigs ^ babi-babi", "pro $\wedge$ profesional", "damn $\wedge$ sial", and "ammo $\wedge$ amunisi". Then, 5 out of 15 are stylistic compensation, such as "goth bling $\wedge$ cincin gothic", "hombre $\wedge$ anak

\footnotetext{
${ }^{23}$ Ibid., p.485.
}

rumahan"”, "doggy bag ^ bungkus", "what in the hell $\wedge$ apa-apaan ini?" and "PCH ^ Santa Monica". Lastly, 4 out of 15 are literal softening, they are "bingewatch ${ }^{\wedge}$ nonton", "hell of a nest ${ }^{\wedge}$ sarang neraka",, "crappy $\wedge$ butut" and "loaded clip ^sibuk”.

\section{B. CONCLUSIONS}

The researcher finds the four types of slang expression in the SL but informality and intimacy are mostly appear as slang expression. It is reasonable because the conversations in the comic are mostly between friends. The slang expression is used to make warmer and closer conversation. However, in translation, the researcher finds out all slang expression has no direct lexical meaning and it causes the translation are using daily used word or colloquial. The researcher also concludes from the three strategies in translating slang expression, literal translation appears most frequent. However, the literal translation is not suitable in translating slang expression because the fact that slang expression does not always have direct lexical meaning in TL will lead reader to misunderstanding or not getting the exact intention of SL's author. Stylistic compensation looks more suitable to translate slang expression in order to cover up the loss (such as there is no direct lexical meaning) in translation.

\section{BIBLIOGRAPHY}

$>$ Books

Alwasilah, A. Chaedar. 1985. Sosiologi

Bahasa. Bandung: Angkasa Bandung.

Baker, Mona. 2011. Routledge Encyclopedia of Translation Studies. London: Routledge. Chapman, Robert L. 1998. Dictionary of American Slang 3rd Edition. 
New York: HarperCollins.

Eble, C.C. 1996. Slang and Sociability. In-Group Language among College Students. London: Chapel Hill.

Eisner, Will. 2006. Comics and Sequential Art. United States: Poorhouse Press.

Karolina, Butkuviene and Petrulione Lolita. 2010. Studies about Langugaes: Translation Peculiarities of Slanguage. No. 16

Lighter, Jonathan E. 1994. Random House Historical Dictionary of American Slang: A-G. Universitas Indiana: Random House.

Mashhady, Habibollah and Pourgalavy, Maryam. 2013. Slang Translation: A Comparative Study of J.D Salinger's The Catcher in The Rye. Finland: Academy Publisher.

Matiello, Elisa. 2007. Keeping Lexical Complexity in Slang Translation, in M. Bertucceli Papi, G. Cappelli \& S. Masi (eds) Lexical Complexity: Theoretical Assesment and Translational Perspectives. Pisa: Edizioni Plus.

Mayvalencia, Della. 2011. An Analysis of Meaning Equivalence of English Slang Language Translation in Whild Child Movie Text. Jakarta: UIN Syarif Hidayatullah.

Moghaddam Nadia G., International Journal of Applied Linguistics \& Wishnubroto Widarso, Bahasa Inggris: dialek, ragam, jargon, slang, blends, clipped words, (Yogyakarta: Kanisius, 1989)

Nadia Ghazanfari Mogghaddam, International Journal of Applied Linguistics \& English Literature: The Effect of Translator's Ideology on the
English Literature: The Effect of Translator's Ideology on the Transmission of Cultural Terms in: "The Joyous Celebration " of "Jalal Al e Ahmad", Vol. 1, No. 2.

Partridge, Eric. 2008. The Concise New Partridge Dictionary of Slang and Unconventional English. New York: Routledge.

Ratna Ningrum, N.A. 2009. An Analysis of Slang Expression Translation in Mean Girls Movie, Surakarta: Sebelas Maret University.

Trudgill, Peter. 1983. Sociolinguistic: An Introduction to Language and Society, UK: Penguin UK.

Venuti, Lawrence. 2012. The Translation Studies Reader. London: Routledge

Widarso, Wishnubroto. 1989. Bahasa Inggris: dialek, ragam, jargon, slang, blends, clipped words. Yogyakarta: Kanisius.

$>\quad$ Websites

Legaudaite, Jolanta, Understanding in Translation. Accessed March 22 ${ }^{\text {nd }}$, 2015.

http://vddb.library.lt/fedora/get/LTeLABA-0001:J.04 2010 IS SN

1392- $\quad$ 561X.N 15.PG 91
98/DS.002.1.01.ARTIC

http://www.meriamwebster.com/thesaurus/jerk\%5Bnou n\%5d. Accessed August 22 2014. http://www.peevish.co.uk/slang/. Accessed April 5 ${ }^{\text {th }}, 2014$.

Transmission of Cultural Terms in: "The Joyous Celebration" of "JalalAl $e$ Ahmad", Vol. 1, No. 2,

Connie C. Eble, Slang and Sociability. In-Group Language among College Students, (London: Chapel Hill, 1996)

Elisa Matiello, Keeping Lexical 
Complexity in Slang Translation, in M. Bertucceli Papi, G. Cappelli \& S. Masi (eds) Lexical Complexity: Theoretical Assesment and Translational Perspectives, (Pisa: Edizioni Plus, 2007)

Duckworth, T. A Dictionary of

Slang, (1996),

http://www.peevish.co.uk/slang/, Accessed April $5^{\text {th }}, 2014$.

Peter Trudgill, Sociolinguistic: An Introduction to Language and Society, (UK: Penguin UK, 1983)

Butkuviene Karolina and Petrulione Lolita, Studies about Langugaes: Translation Peculiarities of Slanguage, (2010). Accessed on April $5^{\text {th }}$, 2014. ISSN 1648-2824 KALBy STUDIJOS, 2010, 16

NR, No. 16

Eugene A. Nida, Principles of Correspondece. In.L. Venuti, (ed), The Translation Studies Reader, (London: Routledge, 2012)

Mona Baker, Routledge Encyclopedia of Translation Studies, (London: Routledge, 2011).

Robert, L. Chapman, Dictionary of American Slang 3rd Edition, (New York: HarperCollins, 1998) p.282.

Jonathan E. Lighter, Random House Historical Dictionary of American Slang: $A-G$, (Universitas Indiana: Random House, 1994) 